\title{
Evaluation of the PNM model for simulating drain flow nitrate-N concentration under manure-fertilized maize
}

\author{
Jean. M. Sogbedji, ${ }^{1,3}$, Harold. M. van Es ${ }^{2}$, Jeff J. Melkonian ${ }^{2}$ \& Robert R. Schindelbeck ${ }^{2}$ \\ ${ }^{1}$ Université de Lomé, Ecole Supériéure d'Agronomie, B.P. 1515, Lomé, Togo. ${ }^{2}$ Department of Crop and Soil \\ Sciences, Cornell University, Ithaca, NY, 14853, USA. ${ }^{3}$ Corresponding author*
}

Received 12 October 2005. Accepted in revised form 1 March 2006

Key words: maize, manure, nitrogen modeling, PNM, soil type

\begin{abstract}
Mathematical models may be used to develop management strategies that optimize the use of nutrients from complex sources such as manure in agriculture. The Precision Nitrogen Management (PNM) model is based on the LEACHN model and a maize $\mathrm{N}$ uptake/growth and yield model and focuses on developing more precise $\mathrm{N}$ management recommendations. The PNM model was evaluated for simulating drain flow nitrate-nitrogen $\left(\mathrm{NO}_{3}-\mathrm{N}\right)$ in a 3-yr study involving different times of liquid manure application on two soil textural extremes, a clay loam and a loamy sand under maize (Zea mays, L.) production. The model was calibrated for major $\mathrm{N}$ transformation rate constants including mineralization, nitrification and denitrification, and its performance was tested using two different calibration scenarios with increasing levels of generalization: (i) separate sets of rate constants for each individual soil type and (ii) a single set of rate constants for both soil types. When calibrated for each manure application treatment for each soil type, the model provided good simulations of monthly and seasonal drain flow $\mathrm{NO}_{3}-\mathrm{N}$ concentrations. The correlation coefficient $(r)$ and Willmott's index of agreement $(d)$ ranged from 0.63 to 0.96 and 0.72 to 0.92 , respectively. The calibrated model performed reasonably well when rate constant values averaged over manure application treatment for each soil type were used, with $r$ and $d$ values between 0.54 and 0.97 , and 0.70 and 0.94 , respectively, and greater accuracy for the clay loam soil. When rate constant values were averaged over manure application treatments and soil types, model performance was reasonably accurate for the fall time manure application on the clay loam ( $r$ and $d$ of 0.60 and 0.91 and 0.72 and 0.92 , respectively) and satisfactory for the spring time on the clay loam and the fall and spring times for the loamy sand soil ( $r$ and $d$ between 0.56 and 0.90 and 0.58 and 0.84 , respectively). The use of the model for predicting $\mathrm{N}$ dynamics under manure-fertilized maize cropping appears promising.
\end{abstract}

\section{Introduction}

Application of manure as a source of nutrients to crop lands is a common practice in the United States (Gupta et al., 2004). Surface and groundwater have become increasingly degraded by nitrate, and this has been attributed to the use of both organic and inorganic fertilizers (Mueller et al., 1995). Conversion from conventional fer-

*E-mail: mianikpo@yahoo.com tilizer management to organic farming has been proposed as a means to reduce water resources degradation. Utilization of the plant-available $\mathrm{N}$ from manure is often poor (Smith and Chambers, 1993), and studies by Ball-Coelho et al. (2004), Gupta et al. (2004), and van Beek et al. (2004) have demonstrated that serious water quality concerns exist regarding the use of manure as a source of crop N. It appears, therefore, that although organic manures contain valuable quantities of $\mathrm{N}$, appropriate management strategies 
for optimizing their use, especially from an environmental perspective, are still inadequately developed primarily due to the complexity and range of manure compositions and associated transformation processes.

\section{Animal manure- $N$ dynamics}

Manure $\mathrm{N}$ includes a somewhat unstable component as urea in the liquid portion and a relatively stable organic $\mathrm{N}$ fraction in the feces (Klausner et al., 1994). If manure is surface applied and not incorporated, the urea may convert quickly to ammonium (through hydrolysis) and then be lost to ammonia as the $\mathrm{pH}$ increases and the manure begins to dry. It may then be lost by ammonia volatilization, depending on ambient conditions (Lauer et al., 1976). If the manure is effectively incorporated, most of the urea is converted to ammonium and nitrate, thereby making it plantavailable or subject to leaching or denitrification losses. The organic $\mathrm{N}$ fraction of manure mineralizes and becomes more gradually plant-available, typically represented by a decay series (Klausner et al., 1994; Magdoff, 1978; Pratt et al., 1973). However, it is recognized that the rate of $\mathrm{N}$ mineralization is strongly affected by variations in soil, weather, manure composition and management factors (Barbarika et al., 1985; Bernal and Kirchmann, 1992; Douglas and Magdoff, 1991; Jackson and Smith, 1997; Klausner et al., 1994). Estimates for mineralization of the organic manure $\mathrm{N}$ fraction are generally lower for manure applied to poorly drained soil or left on the surface (compared to manure incorporated on well-drained soil). Magdoff (1978) estimated that manure $\mathrm{N}$ mineralization rates on a poorly drained clay were about half those on a welldrained loam.

In addition to plant availability, timing of manure application may also affect potential environmental losses. Paul and Zebarth (1997) evaluated leaching losses from fall-applied dairy cattle slurry on two soil types in coastal British Columbia (a poorly drained coarse-textured and a well-drained medium textured soil) and determined them to average $40 \mathrm{~kg} \mathrm{~N} \mathrm{ha}{ }^{-1}$ above the no-manure treatment. Smith and Chambers (1993) in England also determined that the application of high- $\mathrm{N}$ manures in the fall tends to result in excessive nitrate leaching losses and recommended, similar to Hansen et al. (2004), against application during the period September to December. Early spring manure application may result in nitrate release in advance of crop uptake (Durieux et al., 1995), and may also result in leaching losses. Similarly, timing within seasons may have significant impacts on leaching potential. A late fall application, when soil temperatures have decreased, may result in $\mathrm{N}$ release patterns different from early fall application, and more similar to spring application. For example, Gangbazo et al. (1995) and Gupta et al. (2004) did not detect increased $\mathrm{N}$ leaching from late fall and winter-applied manure compared to a check treatment.

\section{Manure- $N$ modeling}

Environmentally sound management of manure in agriculture relies on matching the rate of release of manure $\mathrm{N}$ to the crop demand (Beraud et al., 2005). This requires quantitative characterization of the major manure- $\mathrm{N}$ transformation processes over a range of climates and soil types. Computer simulation models may be used to achieve this goal because they have the capability of integrating many of the processes that occur simultaneously in the soil-plant-atmosphere system. Access to high speed computer facilities means that such models can be used to rapidly assess the impact of different climates, soil types and management practices on the fate of manure-N. The decomposition of organic matter and the transformation of $\mathrm{N}$ in soils are complex microbial processes that are affected by environmental conditions, and computer models offer the ability to interpret, analyze, and optimize these systems where traditional experimental tools fail (Beraud et al., 2005). This is particularly true for manure management where it is desirable to generalize experimental data using models before proceeding to management applications (Borg et al., 1990). Notable modeling efforts related to organic material decomposition and $\mathrm{N}$ cycling in soil include those by Beraud et al. (2005), Borg et al. (1990), Grant et al. (2004), Hadas and Molina (1993), Hadas and Portnoy (1997), Hadas et al. (2004), Marchetti et al. (2005), Melkonian et al. (2004), Molina et al. 
(1990). However, the applicability of most of these research efforts may be hampered by the fact that most models were developed and/or evaluated using laboratory-based data studies where important environmental factors such as temperature and soil wetness were held constant. This does not necessarily simulate conditions in the field where these factors can fluctuate widely at various time scales. Ma and Shaffer (2001) recently reviewed and compared several soil $\mathrm{C}$ and $\mathrm{N}$ dynamics models tested under field conditions (e.g., RZWQM (Ahuja et al., 2000), CERES (Hanks and Ritchie, 1991), NLEAP (Shaffer et al., 1991), and EPIC (Williams, 1995), including the LEACHN component of the PNM model. Each model is unique in the combination of approaches for simulating the major soil $\mathrm{C}$ and $\mathrm{N}$ transformation processes (mineralization, nitrification, denitrification, urea hydrolysis and ammonia volatilization. However, for each individual process, some combinations of the reviewed models adopt similar approaches. A unique attribute of the PNM model compared to many other soil $\mathrm{C}$ and $\mathrm{N}$ models is in the simulation of crop $\mathrm{N}$ uptake, a critical feature because of the impact it has on $\mathrm{C}$ and $\mathrm{N}$ pools, $\mathrm{N}$ movement in soils and soil water relations ( $\mathrm{Ma}$ and Shaffer, 2001).

\section{PNM model}

The Precision Nitrogen Management (PNM) model (Melkonian et al., 2005) is an amalgamation of two other models: LEACHN, the nitrogen module of LEACHM (Hutson, 2003; Hutson and Wagenet, 1992), and a maize $\mathrm{N}$ uptake/ growth and yield model (Sinclair and Muchow, 1995). As part of the PNM model development, the model was re-coded in PYTHON, an interpreted, interactive, object oriented programming language, that links the two models, and the input and output interfaces were reconfigured.

LEACHN is well suited for simulating soil $\mathrm{N}$ processes and has been extensively used and tested in several studies (Jabro et al., 1994; Jemison et al., 1994a,b; Lotse et al., 1992; Sogbedji et al., 2001a,b; Sogbedji et al., 2005). Components of the model have been successfully incorporated into an $\mathrm{N}$-management tool for determining optimal topdress $\mathrm{N}$ rates for winter wheat (Triticum aestivum) crop production (van Alphen and Stoorvogel, 2000). Flows between different pools of $\mathrm{C}$ and $\mathrm{N}$ are simulated in each soil segment as well as on the soil surface. The PNM model uses the capacity water flow option in LEACHN to calculate water and chemical fluxes, which requires that the model run on a daily time step. Equations and descriptions of the processes in LEACHN are presented in Hutson (2003) and Hutson and Wagenet (1992). Critical outputs of the model are the simulation of mineralized $\mathrm{N}$ and $\mathrm{N}$ losses through leaching, denitrification, and volatilization, as well as crop $\mathrm{N}$ uptake and biomass (vegetative and grain) accumulation.

The crop growth subroutine of LEACHN does not allow for sufficient detail in plant response to the environment for physiologically realistic simulations of crop $\mathrm{N}$ uptake, and therefore N leaching (Jemison et al., 1994b; Sogbedji et al., 2001a, b; Sogbedji et al., 2005). The PNM model therefore includes a more sophisticated crop component (maize $\mathrm{N}$ uptake and growth) which is based on a recent maize growth and yield model developed by Sinclair and Muchow (1995). The subroutines of the model incorporate the effects of temperature, solar radiation, water supply and parameters influencing the crop $\mathrm{N}$ budget during the three major phases of maize crop development: vegetative growth, anthesis and grain fill (Muchow and Sinclair, 1991; Muchow et al., 1990; Sinclair and Amir, 1992; Sinclair and Muchow, 1995). Equations and descriptions of the processes in the model are presented in Sinclair and Muchow (1995). The model has been well tested and provides a reasonable fit to data that were collected over a range of conditions and were independent of those used in model development (Sinclair and Muchow, 1995).

The goal of this study was to evaluate the PNM model for its ability to predict shallow groundwater nitrate-N concentrations under manure-fertilized maize fields. Specific objectives were (i) to calibrate the model for mineralization, nitrification, and denitrification rate constants using measured data of drain flow $\mathrm{NO}_{3}-\mathrm{N}$ concentrations from a 3 -yr field study involving dairy cattle manure application to maize on clay loam and loamy sand soils, and (ii) to test the performance of the calibrated model under various levels of generalization of $\mathrm{N}$ rate coefficients. 


\section{Materials and methods}

\section{Lysimeter plots}

Field experimentation was conducted at the Cornell University Research Farm in Willsboro, NY $\left(44^{\circ} 22^{\prime} \mathrm{N}, 73^{\circ} 26^{\prime} \mathrm{W}\right)$. Nutrient transport experiments were conducted on two soil types: a glacio-lacustrine Muskellunge clay loam (fine, mixed, frigid, Aeric Epiaqualf), and a Stafford loamy fine sand (mixed, mesic typic Psammaquent) that has formed in outwash sand, but is underlain by glacio-lacustrine clay at depths ranging from 0.6 to $1.5 \mathrm{~m}$. For each soil type, sixteen lysimeter plots in a four-by-four pattern (Figure 1) were established in 1987 and 1992 for the clay loam and loamy sand site, respectively. The plots are surrounded by a $0.8 \mathrm{~mm}$-thick impermeable PVC geomembrane to a depth of $1.8 \mathrm{~m}$ to make them hydrologically independent, as described in further detail by Sogbedji et al. (2000). A central drain line, installed at $0.9 \mathrm{~m}$ depth, of each pair of plots is joined outside the plot boundaries at an access hole midway between the two plots, allowing for sampling of drainage water, as discussed in further detail by van Es et al. (2004).

The plots were used for maize-based $\mathrm{N}$ fertilizer experiments during the 1992-1995 growing seasons (Sogbedji et al., 2000, 2001a, b). Two strips of four plots at each site were converted to orchard grass in the spring of 1996 (Figure 1) and the other plots remained under maize in 1996 and 1997 with Pre-Sidedress Nitrate Test (PSNT)-based fertilizer rates (Magdoff, 1991). This manure application study was initiated in October 1997 and continued through October 2000. Previous research efforts have demonstrated that the plots function well for nutrient leaching studies and allow for considerable precision in detecting subtle tracer and $\mathrm{N}$ fertilizer treatment effects (Sogbedji et al., 2000; van Es et al., 1991). Previous studies also showed that the clay loam plots experience longer periods of saturation in the surface horizon than the loamy sand plots (van Es et al., 2005) and have higher $\mathrm{N}$ losses through denitrification (Sogbedji et al., 2001a,b). The loamy sand plots showed higher $\mathrm{NO}_{3}-\mathrm{N}$ leaching losses than the clay loam plots (Sogbedji et al., 2000). For this paper, only drain

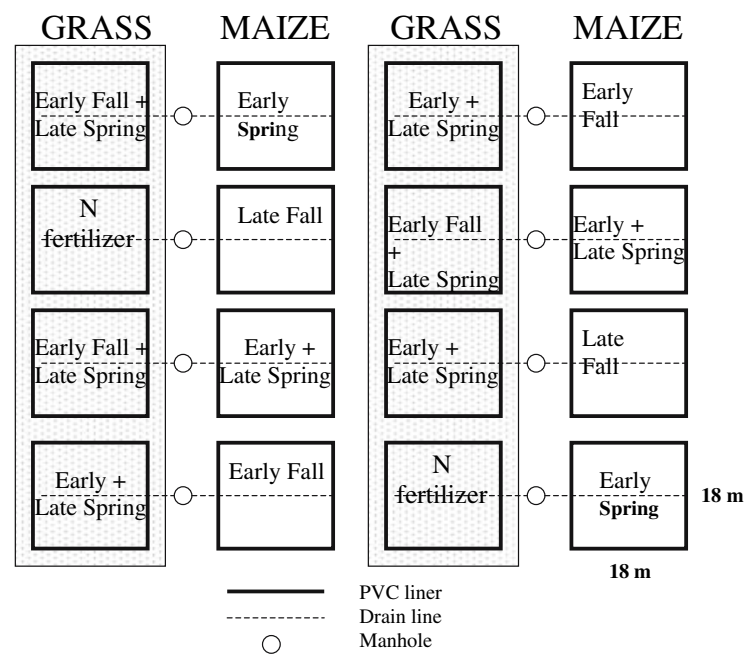

Figure 1. Plot layout and experimental design for manure and $\mathrm{N}$ fertilizer application study on the clay loam site. The loamy sand site has an identical experiment design except that plots are $14 \times 14 \mathrm{~m}$ and only have a single central drain in each plot.

flow $\mathrm{NO}_{3}-\mathrm{N}$ concentration data collected from plots under maize were used.

\section{Crop, soil and drainage water management}

Four different times of manure application were allocated as treatments to plots at each of the two sites using a spatially balanced complete block design (van Es and van Es, 1993) with two replications (Figure 1): Early Fall (target date 1 October), Late Fall (target date 1 November), Early Spring (target date 15 April) and a split application with half applied in Early Spring, and the remainder applied as sidedress in Late Spring (target date 15 June). Liquid manure was surface-applied to plots using a Nuhn Industries (Sebringville, On, Canada) manure applicator. Manure was sampled prior to application and analyzed for nutrient content and liquidity (Table 1). Manure was applied at a total annual rate of $93,800 \mathrm{~L} \mathrm{ha}^{-1}$ in one application for Early Fall, Late Fall and Early Spring applications. For the springtime split application, two equal amounts of $46,900 \mathrm{~L} \mathrm{ha}^{-1}$ were applied. These rates were chosen to supply the maize $\mathrm{N}$ requirements for spring applications, and thereby not exceed agronomic optimum rates. Manure applications on maize were disc-incorporated (twice) 
within $1 \mathrm{hr}$ after application, except for the late-spring sidedress application which utilized a four-unit drop hose system equipped with S-tine cultivators for immediate incorporation of manure between crop rows.

Maize (cv. Agway 262) was planted at a rate of 72,000 kernels ha ${ }^{-1}$ on 13 May 1998, 12 May 1999 and 15 May 2000. Starter fertilizer was planter applied in a band at a rate of $265 \mathrm{~kg} \mathrm{ha}^{-1}$ of 20-10-10 (1998) or 15-15-15 (1999 and 2000). In addition, supplemental sidedress fertilizer was applied as urea-ammonium nitrate solution based on the results of a PSNT (Magdoff, 1991) from soil samples collected from the 0 to 30-cm depth on 27 May 1998, 10 June 1999, and 22 June 2000. This resulted in varying amounts of $\mathrm{N}$ being applied to each treatment, but provides realistic $\mathrm{N}$ management scenarios that account for greater needs for supplemental $\mathrm{N}$ fertilizer from fall manure applications. For 1999 and 2000, sidedress rates were consistent among the treatments for each soil type. No sidedress $\mathrm{N}$ fertilizer was applied to plots that received early spring + late spring (sidedress) manure applications. Further details on timing of manure application, manure $\mathrm{N}$ content, and total $\mathrm{N}$ applications are provided in Table 1. The maize crop was managed according to Cornellrecommended guidelines for pest control and nutrients (Cornell Cooperative Extension, 1997).

Drain effluent was manually sampled using polyethylene bottles during periods of drain discharge, generally in the spring, early summer, and fall. Water samples were obtained at least weekly during flow periods, more often during periods following manure applications. All water samples were immediately frozen after sampling. $\mathrm{NO}_{3}-\mathrm{N}$ content was determined for each sample using an autoanalyzer at the Cornell University Nutrient Analysis Laboratory (Cornell Nutrient Analysis Laboratories, 1987, 1989). Monthly and seasonal average drain flow $\mathrm{NO}_{3}-\mathrm{N}$ concentrations were determined from the daily flow sample concentrations. Based on drain discharge patterns, seasonal periods were defined as: Winter 97-98 (30 September 1997 to 20 April 1998), Growing Season 98 (21 April to 3 September 1998), Winter 98-99 (4 September 1998 to 3

Table 1. Manure and fertilizer N application schedule for lysimeter plots during 1997-2000

\begin{tabular}{|c|c|c|c|c|c|c|c|}
\hline \multirow[t]{2}{*}{ Treatment } & \multirow{2}{*}{$\begin{array}{l}\text { Manure } \\
\text { application } \\
\text { date }\end{array}$} & \multicolumn{6}{|c|}{ Application rate } \\
\hline & & $\begin{array}{l}\text { Manure, } \\
\mathrm{L} \mathrm{ha}^{-1}\end{array}$ & $\begin{array}{l}\text { Manure } \\
\text { solid } \\
\text { content, } \\
\mathrm{g} \mathrm{L}^{-1}\end{array}$ & $\begin{array}{l}\text { Manure } \\
\text { inorganic } \\
\mathrm{N} \text { content, } \\
\mathrm{mg} \mathrm{L}^{-1}\end{array}$ & $\begin{array}{l}\text { Manure } \\
\text { organic } \\
\mathrm{N} \text { content, } \\
\mathrm{mg} \mathrm{L}^{-1}\end{array}$ & $\begin{array}{l}\text { Fertilizer, } \\
\mathrm{kg} \mathrm{ha}^{-1}\end{array}$ & $\begin{array}{l}\text { Total annual } \\
\mathrm{N} \text { applied } \\
\mathrm{kg} \mathrm{ha}^{-1}\end{array}$ \\
\hline Early fall & 30 Sept. 1997 & 93,800 & 70 & 772 & 1119 & 71 & 248 \\
\hline Late fall & 30 October 1997 & 93,800 & 69 & 792 & 1188 & 71 & 257 \\
\hline Early spring & 15 April 1998 & 93,800 & 70 & 921 & 1356 & 88 & 302 \\
\hline $\begin{array}{l}\text { Early + late } \\
\text { spring }\end{array}$ & $\begin{array}{l}15 \text { Apr. }+ \\
17 \text { June } 1998\end{array}$ & $\begin{array}{l}46,900+ \\
46,900\end{array}$ & 70,83 & 921,990 & 1356,1287 & 53 & 260 \\
\hline Early fall & 13 October 1998 & 93,800 & 48 & 525 & 990 & $68^{\mathrm{b}}$ & 210 \\
\hline Late fall & 5 Nov. 1998 & 93,800 & 61 & 693 & 1089 & 68 & 235 \\
\hline Early spring & 15 April 1999 & 93,800 & 66 & 822 & 1188 & 40 & 228 \\
\hline $\begin{array}{l}\text { Early + late } \\
\text { spring }\end{array}$ & $\begin{array}{l}15 \text { Apr. }+ \\
18 \text { June } 1999\end{array}$ & $\begin{array}{l}46,900+ \\
46,900\end{array}$ & 66,96 & 822,812 & 1188,1198 & 40 & 229 \\
\hline Early fall & 29 Sept. 1999 & 93,800 & 83 & 911 & 1455 & 140 & 362 \\
\hline Late fall & 28 October 1999 & 93,800 & 71 & 663 & 1327 & 140 & 327 \\
\hline Early spring & 20 April 2000 & 93,800 & 80 & 782 & 1287 & 140 & 334 \\
\hline $\begin{array}{l}\text { Early + late } \\
\text { spring }\end{array}$ & $\begin{array}{l}20 \text { Apr. }+ \\
23 \text { June } 2000\end{array}$ & $\begin{array}{l}46,900+ \\
46,900\end{array}$ & 80,68 & 782,931 & 1287,1356 & 40 & 245 \\
\hline
\end{tabular}

${ }^{\text {a }}$ Total annual $\mathrm{N}$ applications are based on the period September to August. Fertilizer rates reflect those applied in the growing season following manure application.

${ }^{\mathrm{b}}$ In 1998 sidedress rates varied among soil types. Rates reflect those for the clay loam; N applications were 93, 53, 53, and 53 kg ha ${ }^{-1}$ for the early fall, late fall, early spring, and early + late spring treatments, respectively for the loamy sand. 
April 1999), Growing Season 99 (4 April to 8 September 1999), Winter 99-00 (9 September 1999 to 22 April 2000), and Growing Season 2000 (23 April to 25 September 2000). There was no drain flow in the Growing Season 1999 due to a drought.

\section{PNM model input data}

Input data for the PNM model include soil physical and chemical properties as well as weather and crop data. The soil physical properties include: saturated hydraulic conductivity, bulk density and water retention curve, which were measured from 76- $\mathrm{mm}$ diameter soil cores for both sites during an earlier study, as discussed in Sogbedji et al. (2001a, Table 2). The water flow routine in PNM (LEACHN) uses equations proposed by Campbell (1974) to relate volume frac- tional water content, pressure potential and hydraulic conductivity.

The soil chemical properties required for the model include: initial organic $\mathrm{C}$ and inorganic $\mathrm{N}$ contents. Soil samples were collected on 30 September 1997 prior to manure application from five depths $(0-1.0 \mathrm{~m}$ at $0.20 \mathrm{~m}$ intervals $)$ using two composited cores from each plot on each soil type. All holes created by soil coring were carefully backfilled. Soil organic $\mathrm{C}$ and inorganic $\mathrm{N}$ contents were determined at the Cornell University Nutrient Analysis Laboratory (1987, 1989). Also, particle size distribution was determined for each soil type using the pipette methods (Gee and Bauder, 1986). The soil-related input data used for the simulations are presented in Table 2.

Crop-related information required for the model apart from planting date include growing

Table 2. Soil physical and chemical properties of clay loam and loamy sand plots

\begin{tabular}{|c|c|c|c|c|c|c|c|c|c|c|c|c|c|c|}
\hline \multirow[t]{3}{*}{$\begin{array}{l}\text { Depth, } \\
\mathrm{cm}\end{array}$} & \multirow{3}{*}{$\begin{array}{l}\text { Bulk } \\
\text { density, } \\
\mathrm{mg} \mathrm{m}^{-3}\end{array}$} & \multicolumn{3}{|c|}{ Particle size } & \multirow[t]{3}{*}{$\begin{array}{l}\mathrm{K}_{\text {sat }}^{\mathrm{a}} \\
\mathrm{mm} \mathrm{d}^{-1}\end{array}$} & \multicolumn{6}{|c|}{$\begin{array}{l}\text { Water content, } \mathrm{m}^{3} \mathrm{~m}^{-3} \text { at pressure } \\
(\mathrm{kPa})\end{array}$} & \multirow{2}{*}{\multicolumn{2}{|c|}{$\begin{array}{l}\begin{array}{l}\text { Initial } \mathrm{N} \text { and } \mathrm{C} \\
\text { contents }\end{array} \\
\text { Inorganic } \mathrm{N}\end{array}$}} & \multirow[t]{3}{*}{$\begin{array}{l}\text { Organic } \\
\text { C } \%\end{array}$} \\
\hline & & \multirow{2}{*}{$\begin{array}{l}\text { Sand, } \\
\mathrm{g} \mathrm{kg}^{-1}\end{array}$} & \multirow{2}{*}{$\begin{array}{l}\text { Silt, } \\
\mathrm{g} \mathrm{kg}^{-1}\end{array}$} & \multirow{2}{*}{$\begin{array}{l}\text { Clay, } \\
\mathrm{g} \mathrm{kg}^{-1}\end{array}$} & & \multirow[t]{2}{*}{1} & \multirow[t]{2}{*}{10} & \multirow[t]{2}{*}{40} & \multirow[t]{2}{*}{100} & \multirow[t]{2}{*}{300} & \multirow[t]{2}{*}{1500} & & & \\
\hline & & & & & & & & & & & & $\begin{array}{l}\mathrm{NH}_{4} \\
\mathrm{mg} \mathrm{kg}^{-1}\end{array}$ & $\begin{array}{l}\mathrm{NO}_{3} \\
\mathrm{mg} \mathrm{kg}^{-1}\end{array}$ & \\
\hline \multicolumn{15}{|c|}{ Clay loam } \\
\hline 5 & 1.16 & 445 & 171 & 384 & 5471 & 0.47 & 0.34 & 0.32 & 0.23 & 0.19 & 0.17 & & & \\
\hline 15 & 1.43 & 423 & 153 & 424 & 7413 & 0.40 & 0.36 & 0.34 & 0.28 & 0.24 & 0.22 & 2.96 & 30.60 & 3.0 \\
\hline 25 & 1.53 & 293 & 168 & 539 & 1360 & 0.43 & 0.39 & 0.38 & 0.35 & 0.31 & 0.27 & 1.80 & 11.51 & \\
\hline 35 & 1.49 & 122 & 264 & 608 & 1176 & 0.45 & 0.43 & 0.41 & 0.39 & 0.34 & 0.31 & & & \\
\hline 45 & 1.51 & 48 & 275 & 677 & 446 & 0.42 & 0.40 & 0.38 & 0.36 & 0.34 & 0.31 & 1.15 & 3.81 & 0.5 \\
\hline 55 & 1.51 & & & & 905 & 0.45 & 0.43 & 0.42 & 0.41 & 0.37 & 0.34 & 1.04 & 3.52 & \\
\hline 65 & 1.52 & 66 & 241 & 693 & 109 & 0.45 & 0.42 & 0.41 & 0.40 & 0.38 & 0.34 & & & \\
\hline 75 & 1.55 & & & & 52 & 0.44 & 0.42 & 0.41 & 0.39 & 0.35 & 0.32 & 1.01 & 3.37 & 0.3 \\
\hline 85 & 1.57 & 32 & 164 & 804 & 446 & 0.45 & 0.43 & 0.41 & 0.39 & 0.37 & 0.34 & 1.09 & 3.34 & \\
\hline \multicolumn{15}{|c|}{ Loamy sand } \\
\hline 5 & 1.25 & 798 & 101 & 101 & 10,163 & 0.45 & 0.25 & 0.21 & 0.15 & 0.08 & 0.07 & & & \\
\hline 15 & 1.52 & 806 & 100 & 94 & 24,614 & 0.38 & 0.25 & 0.22 & 0.10 & 0.09 & 0.08 & 2.08 & 37.42 & 1.6 \\
\hline 25 & 1.55 & 869 & 58 & 73 & 5346 & 0.35 & 0.23 & 0.21 & 0.09 & 0.07 & 0.06 & 1.16 & 13.96 & \\
\hline 35 & 1.69 & 848 & 55 & 97 & 5228 & 0.28 & 0.17 & 0.15 & 0.09 & 0.07 & 0.06 & & & \\
\hline 45 & 1.51 & 738 & 120 & 142 & 826 & 0.32 & 0.24 & 0.22 & 0.17 & 0.14 & 0.12 & 0.57 & 3.75 & 0.4 \\
\hline 55 & 1.50 & & & & 4314 & 0.35 & 0.25 & 0.23 & 0.18 & 0.14 & 0.13 & 0.91 & 2.78 & \\
\hline 65 & 1.54 & 503 & 209 & 288 & 3554 & 0.41 & 0.30 & 0.29 & 0.25 & 0.21 & 0.16 & & & \\
\hline 75 & 1.56 & 207 & 320 & 437 & 289 & 0.44 & 0.41 & 0.40 & 0.36 & 0.32 & 0.29 & 1.35 & 2.76 & 0.2 \\
\hline 85 & 1.44 & 67 & 206 & 727 & 136 & 0.44 & 0.42 & 0.41 & 0.38 & 0.35 & 0.31 & 1.36 & 1.98 & \\
\hline
\end{tabular}

${ }^{\mathrm{a}} K_{\text {sat }}$ measured from $76 \mathrm{~mm}$ diameter cores using constant head method (Klute and Dirksen, 1986). ${ }^{\mathrm{b}}$ Soil $\mathrm{NH}_{4}-\mathrm{N}, \mathrm{NO}_{3}-\mathrm{N}$ and organic $\mathrm{C}$ contents were determined using an autoanalyzer at the Cornell University Nutrient Analysis Laboratory (Cornell Nutrient Analysis Laboratories, 1987, 1989). 
degree day to emergence and growing degree day to maturity which were provided by W. J. Cox (pers.commun.. The assumed rooting depth for each soil type $(60 \mathrm{~cm}$ for clay loam and $70 \mathrm{~cm}$ for loamy sand) was based on earlier work by Sogbedji et al. (2001a). Other crop input data are minimum and maximum grain $\mathrm{N}$ contents, minimum and maximum stem $\mathrm{N}$ contents, and minimum specific leaf $\mathrm{N}$, which were based on Sinclair and Muchow (1995). Daily precipitation, air temperature, and solar radiation were collected at the farm meteorological station managed by the Northeast Regional Climate Center at Cornell University.

Sensitivity analyses of the $\mathrm{N}$ module (LEACHN) of the PNM model by Hutson and Wagenet (1991) and other studies by Jemison et al. (1994b), Lotse et al. (1992), Sogbedji et al. (2001a) and Sogbedji et al. (2005) indicated that the model output was affected by small changes in rates constants for equations describing mineralization, nitrification and denitrification. Changes in ammonia volatilization rate did not significantly affect simulations when inorganic fertilizer and manure are incorporated (Melkonian et al. 2005; Sogbedji et al. 2001a, 2005). Melkonian et al. (2005) found a similar sensitivity for the PNM model. Therefore, a default value of $0.06 \mathrm{~d}^{-1}$ for the volatilization rate constant was used in this study. The $\mathrm{C}: \mathrm{N}$ ratio was not measured in this study, but the value of 10.0 was used based on research results published by Külling et al. (2001) and Sorensen et al. (2003). Additional parameter input values for the $\mathrm{N}$ module except those that were calibrated, were obtained from Hutson and Wagenet (1992), Jansson and Anderson (1988), and Johnsson et al. (1987, Table 3).

\section{Model calibration}

The PNM model was calibrated to fit the 3-yr period (1997-2000) drain flow $\mathrm{NO}_{3}-\mathrm{N}$ concentration data. This time period offered the advantage of having highly variable seasonal rainfall (426249 and $347-123 \mathrm{~mm}$ for the winter and growing season periods, respectively, as discussed in further detail by van Es et al. (2005)), which insured that the model was calibrated to a wide range of climate conditions. The model was calibrated for each of the four treatments (represented by
Table 3. LEACHMN parameter input values used in the PNM model simulations

\begin{tabular}{ll}
\hline Parameter & Input values \\
\hline Partition coefficient, $\mathrm{NH}_{4}-\mathrm{N}$ & $3.0 \mathrm{~L} \mathrm{~kg}^{-1}$ \\
Partition coefficient, $\mathrm{NO}_{3}-\mathrm{N}$ & $0.0 \mathrm{~L} \mathrm{~kg}^{-1}$ \\
Denitrification half saturation constant & $10 \mathrm{mg} \mathrm{L}^{-1}$ \\
Litter mineralization rate constant & 0.01 day $^{-1}$ \\
$\mathrm{Q}_{10}$ factor & 2.0 \\
$\mathrm{C}: \mathrm{N}$ ratio for biomass and humus & 10.0 \\
Maximum $\mathrm{NO}_{3} / \mathrm{NH}_{4}$-ration & 8.0 \\
in solution to control nitrification rate & \\
\hline
\end{tabular}

${ }^{a}$ All parameter values in the simulations were selected from Hutson and Wagenet (1992), Jansson and Anderson (1988) and Johnsson et al. (1987).

different timing of manure application). Based on sensitivity analyses (Hutson and Wagenet, 1991) and other evaluation studies of the LEACHMN model (Jemison, 1991; Jemison et al., 1994b; Lotse et al., 1992; Sogbedji et al., 2001a,b, 2005), we calibrated the model by performing multiple runs and sequentially adjusting the following input parameters: (1) denitrification rate constant, (2) manure mineralization rate constant, (3) native organic matter mineralization rate constant, and (4) nitrification rate constant. Simulations covered the period from 30 September 1997 to 1 October 2000. The calibration consisted of slight increases or decreases of each rate constant within a range of published values (Table 4) during each run to achieve the closest agreement between simulated and measured monthly and seasonal drain flow $\mathrm{NO}_{3}-\mathrm{N}$ concentrations for the 3 -yr period. Calibration was completed when adjustments to the specific rate constants no longer reduced the difference between measured mean and simulated data of $\mathrm{NO}_{3}-\mathrm{N}$ concentrations in drain flow. The methods of Addiscott and Whitmore (1987) were followed, using a positive, highly significant correlation coefficient $(r)$, and a reduced mean difference between simulated and measured data as criteria for goodness-of-fit of model predictions. To assess the accuracy of simulations, both graphical and statistical methods (Loague and Green, 1991; Willmott, 1981) were used. Simulated values were plotted against the corresponding measured values on a 1:1 scale to examine trends. A linear relationship was assumed between measured and simulated data and a normal distribution between the data sets. 
Table 4. Range of rate constant values tested for model calibration

\begin{tabular}{|c|c|c|}
\hline Rate constant & Range tested $\left(\right.$ day $\left.^{-1}\right)$ & Sources \\
\hline $\begin{array}{l}\text { Native organic matter } \\
\text { mineralization }\end{array}$ & $7 \times 10^{-5}-0.15 \times 10^{-3}$ & Borg et al. (1990), Hutson and Wagenet (1992), Lotse et al. (1992) \\
\hline Manure mineralization & $0.00012-0.035$ & $\begin{array}{l}\text { Borg et al. (1990), Lotse et al. (1992), Jemison et al. (1994b), } \\
\text { Eghball (2000), Beraud et al. (2005) }\end{array}$ \\
\hline Nitrification & $0.1-0.5$ & $\begin{array}{l}\text { Johnsson et al. (1987), Jansson and Anderson (1988), Borg et al. (1990), } \\
\text { Hutson and Wagenet (1992), Lotse et al.(1992), Jemison et al. (1994b) }\end{array}$ \\
\hline Denitrification & $0.0-0.15$ & $\begin{array}{l}\text { Johnsson et al. (1987), Jansson and Anderson (1988), Borg et al. (1990), } \\
\text { Hutson and Wagenet (1992), Lotse et al. (1992), Jemison et al. (1994b), } \\
\text { Desmond and Ward (2000) }\end{array}$ \\
\hline
\end{tabular}

PROC REG of the SAS software package (SAS Institute, 2004) was used to conduct least squares regression analysis and to compare the slope and intercept to 1.0 and 0.0 , respectively. The root mean square error (RMSE) was compared to the mean measured value (normalized root mean square error, NRMSE) to determine the prediction error. Willmott's index of agreement $(d)$ was calculated, whose value reflects the degree to which the simulated variation accurately estimates the measured variation (1.0 means a perfect agreement between simulated and measured values. RMSE, NRMSE, and $d$ are defined as follows:

$$
\begin{aligned}
& \mathrm{RMSE}=\left[\sum_{i=1}^{n}\left(o_{i}-s_{i}\right)^{2} / n\right]^{0.5} \\
& \mathrm{NRMSE}=\mathrm{RMSE} / o \\
& d=1-\frac{\sum_{i=1}^{n}\left(o_{i}-s_{i}\right)^{2}}{\sum_{i=1}^{n}\left(\left|o_{i}^{\prime}\right|+\left|s_{i}^{\prime}\right|\right)^{2}}
\end{aligned}
$$

where $o_{i}^{\prime}=o_{i}-o$ and $s_{i}^{\prime}=s_{i}-o$ where $n$ is the number of observations, $o_{i}$ is the observed value, and $S_{i}$ is the corresponding simulated value, and $o$ is the mean observed value.

\section{Model performance}

It is typically unknown whether calibrated models can be used to generalize process simulations to other spatial and temporal domains. Can rate constants determined from a single soil type be generalized over a multitude of soil types? Can calibrated rate constants for a given manure timing treatment provide realistic simulations when used for any other management approaches? Can rate constants determined for a single or a few years be appropriately used in long-term simulations? Several proposed model testing methods are discussed by Donnigan (1983), Jemison (1991), and van Keulen (1976). In this study, the performance of the calibrated PNM model was tested with the 3-yr period of drain flow $\mathrm{NO}_{3}-\mathrm{N}$ concentration data using the Jemison (1991) approach in two calibration scenarios with increasing levels of generalization: (i) separate transformation rate constants for each soil type based on average values of calibrated rate constants over the four manure timing treatments and (ii) a single set of rate constants based on the average values of the calibrated rate constants over the manure timing treatments and the soil types. For each of the two scenarios, measured and simulated monthly and seasonal drain flow $\mathrm{NO}_{3}-\mathrm{N}$ concentrations under each manure timing treatment and soil type were compared. The graphical and statistical methods described in the calibration section were used for the comparisons.

\section{Results}

\section{Manure and fertilizer $N$ data}

Manure analyses showed that its nutrient and solid matter contents were somewhat variable throughout the study period, but still allow for 
valid comparison of the effects of timing of application (Table 1). Solid contents ranged from 48 to $96 \mathrm{~g} \mathrm{~L}^{-1}$, manure inorganic and organic $\mathrm{N}$ contents ranged from 525 to 921 (all but one application time between 663 and $921 \mathrm{mg} \mathrm{L}^{-1}$ ) and 990 to $1455 \mathrm{mg} \mathrm{L}^{-1}$, respectively. Average total $\mathrm{N}$ content of manure was $2 \mathrm{~g} \mathrm{~L}^{-1}$, of which approximately $40 \%$ was inorganic, while the remainder was in the organic fraction. The 46,900 and 93,800 $\mathrm{L} \mathrm{ha}^{-1}$ applications resulted in average applications of approximately 96 and $191 \mathrm{~kg} \mathrm{ha}^{-1}$ of total $\mathrm{N}$, respectively. The higher manure $\mathrm{N}$ contents were generally associated with the spring applications, implying that, given equal liquid manure application volumes, the spring applications involved higher $\mathrm{N}$ rates. This was compensated by lower PSNT-based $\mathrm{N}$ fertilizer rates for spring compared to the fall application times, and the manure $\mathrm{N}$ applications therefore represented a real-world scenario. Annual average fertilizer $\mathrm{N}$ application was $105 \mathrm{~kg} \mathrm{ha}^{-1}$ for the early fall and late fall treatments, $89 \mathrm{~kg} \mathrm{ha}^{-1}$ for the early spring treatment and $44 \mathrm{~kg} \mathrm{ha}^{-1}$ for the early + late spring, which did not receive side-dress $\mathrm{N}$ fertilizer. The manure and fertilizer $\mathrm{N}$ applications resulted in average total $\mathrm{N}$ applications ranging from 245 to $288 \mathrm{~kg} \mathrm{ha}^{-1} \mathrm{y}^{-1}$ (Table 1). Three-year total $\mathrm{N}$ applications on maize were $857,856,864$, and $734 \mathrm{~kg} \mathrm{ha}^{-1}$ for early fall, late fall, early spring, and early + late spring treatments, respectively.

\section{PNM model input data}

The clay loam plots contain some sand size material in the 0 to $35-\mathrm{cm}$ depth, but high clay content in the subsoil (Table 2). The loamy sand site shows low clay contents in the subsurface layer and as high as $727 \mathrm{~g} \mathrm{~kg}^{-1}$ at $85 \mathrm{~cm}$ depth. Textural fractions are intermediate in the 50 to $80-\mathrm{cm}$ depth range, but this mostly reflects the effect of averaging varying depths of the sharp interface between the outwash sand and the underlying glacio-lacustrine clay. Water retention and hydraulic conductivity $\left(K_{\text {sat }}\right)$ data generally show higher and lower values, respectively, based on clay content (Table 2). For the two soil types, bulk density values were lowest for the top layer. For the remaining depth intervals of the soil profile, values were generally similar for the clay loam soil, but varied for the loamy sand soil due to layering in the glacial outwash material. Initial soil inorganic $\mathrm{N}$ contents were similar for the two soil types (typically 11 and $12 \mathrm{mg} \mathrm{kg}^{-1}$ on average for the $0.9 \mathrm{~m}$ soil profile for the clay loam and loamy sand soils, respectively), and were consistently dominated by the $\mathrm{NO}_{3}-\mathrm{N}$ species at all depth intervals of the soil profile (Table 2). Organic $\mathrm{C}$ content was higher for the top soil on the clay loam than for the loamy sand, but was similar for the two soil type at the other depth intervals.

\section{Model calibration}

The calibrated $\mathrm{N}$ transformation rate constants are presented in Table 5. The nitrification rate constant was identical for all manure timing treatments on each soil type. The mineralization and denitrification rate constants did not vary within season, but varied between the fall and the spring application timings for each soil type. Rate constants for manure mineralization and nitrification were on average lower for the clay loam than for the loamy sand, but the denitrification rate constant was higher.

Simulated and measured monthly average drain flow $\mathrm{NO}_{3}-\mathrm{N}$ concentrations were in general reasonably close to each other (mean difference ranging from -3.9 to $0.1 \mathrm{mg} \mathrm{L}^{-1}$, Table 6), and followed similar trends with a general pattern of the model tending to overestimate drain flow $\mathrm{NO}_{3}-\mathrm{N}$ concentrations on both the clay loam and loamy sand soils (Figure 2). For the clay loam soil, the RMSE ranged from 2.8 to $6.7 \mathrm{mg} \mathrm{L}^{-1}$, leading to prediction errors (NRMSE) between 31 and $50 \%$ for the 3 -yr period measured mean values (Table 6). The correlation coefficient $(r)$ and the Willmott's index of agreement $(d)$ ranged from 0.63 to 0.73 and 0.72 to 0.84 , respectively, indicating a good match between simulated and measured data. The slopes (0.6-0.8) and the intercept $\left(0.9-2.3 \mathrm{mg} \mathrm{L}^{-1}\right)$ were significantly less than 1.0 and not significantly different from 0.0 , respectively, at $\alpha=0.05$. This demonstrates as discussed earlier based on Figure 2, the tendency of the model to overestimate measured data. For the loamy sand soil, the RMSE values were between 5.3 and $10.7 \mathrm{mg} \mathrm{L}^{-1}$ and resulted in prediction errors from 42 to $57 \%$ for the 3-yr measured mean values (Table 6). The 
Table 5. $\mathrm{N}$ transformation rate constants adjusted to optimize the fit between simulated and measured drain flow $\mathrm{NO}_{3}-\mathrm{N}$ concentration

\begin{tabular}{|c|c|c|c|c|}
\hline $\begin{array}{l}\text { Treatments (timing of } \\
\text { manure application) }\end{array}$ & $\begin{array}{l}\text { Mineralization (native } \\
\text { organic matter) }, \mathrm{d}^{-1}\end{array}$ & $\begin{array}{l}\text { Mineralization } \\
\text { (manure) }, \mathrm{d}^{-1}\end{array}$ & $\begin{array}{l}\text { Nitrification, } \\
\mathrm{d}^{-1}\end{array}$ & $\begin{array}{l}\text { Denitrification, } \\
\mathrm{d}^{-1}\end{array}$ \\
\hline \multicolumn{5}{|l|}{ Clay loam } \\
\hline Early fall & $6 \times 10^{-5}$ & 0.010 & 0.150 & 0.050 \\
\hline Late fall & $6 \times 10^{-5}$ & 0.010 & 0.150 & 0.050 \\
\hline Early spring & $5 \times 10^{-5}$ & 0.008 & 0.150 & 0.070 \\
\hline Early + late spring & $5 \times 10^{-5}$ & 0.008 & 0.150 & 0.070 \\
\hline Site average & $5.5 \times 10^{-5}$ & 0.009 & 0.150 & 0.060 \\
\hline \multicolumn{5}{|l|}{ Loamy sand } \\
\hline Early fall & $6 \times 10^{-5}$ & 0.015 & 0.200 & 0.020 \\
\hline Late fall & $6 \times 10^{-5}$ & 0.015 & 0.200 & 0.020 \\
\hline Early spring & $5 \times 10^{-5}$ & 0.010 & 0.200 & 0.033 \\
\hline Early + late spring & $5 \times 10^{-5}$ & 0.010 & 0.200 & 0.033 \\
\hline Site average & $5.5 \times 10^{-5}$ & 0.012 & 0.200 & 0.026 \\
\hline Accross site average & $5.5 \times 10^{-5}$ & 0.010 & 0.175 & 0.043 \\
\hline
\end{tabular}

Table 6. Statistics for simulation of drain flow $\mathrm{NO}_{3}-\mathrm{N}$ concentration by the $\mathrm{PNM}$ model during calibration

\begin{tabular}{|c|c|c|c|c|c|c|c|c|}
\hline \multirow[t]{2}{*}{ Statistics } & \multicolumn{4}{|c|}{ Clay loamy } & \multicolumn{4}{|c|}{ Loamy sand } \\
\hline & $\begin{array}{l}\text { Early } \\
\text { fall }\end{array}$ & $\begin{array}{l}\text { Late } \\
\text { fall }\end{array}$ & $\begin{array}{l}\text { Early } \\
\text { spring }\end{array}$ & $\begin{array}{l}\text { Early + late } \\
\text { spring }\end{array}$ & $\begin{array}{l}\text { Early } \\
\text { fall }\end{array}$ & $\begin{array}{l}\text { Late } \\
\text { fall }\end{array}$ & $\begin{array}{l}\text { Early } \\
\text { spring }\end{array}$ & $\begin{array}{l}\text { Early + late } \\
\text { spring }\end{array}$ \\
\hline \multicolumn{9}{|c|}{ Monthly simulations } \\
\hline Mean difference & -3.7 & -2.5 & -1.3 & 0.1 & -3.7 & -3.9 & -1.9 & -0.9 \\
\hline RMSE & 6.7 & 4.7 & 3.4 & 2.8 & 8.6 & 10.7 & 6.3 & 5.3 \\
\hline NRMSE & 0.50 & 0.38 & 0.42 & 0.31 & 0.46 & 0.57 & 0.56 & 0.42 \\
\hline$r$ & 0.63 & 0.72 & 0.73 & 0.66 & 0.76 & 0.70 & 0.65 & 0.77 \\
\hline Slope & $0.6^{*}$ & $0.8^{*}$ & $0.7^{*}$ & $0.8^{*}$ & $1.1 *$ & $0.6^{*}$ & $0.8^{*}$ & $1.2^{*}$ \\
\hline Intercept & 2.3 & 1.0 & 0.9 & 1.9 & -6.0 & 4.2 & 0.4 & -4.4 \\
\hline$d$ & 0.72 & 0.81 & 0.84 & 0.80 & 0.86 & 0.81 & 0.78 & 0.82 \\
\hline \multicolumn{9}{|c|}{ Seasonal simulations } \\
\hline Mean difference & -0.8 & -1.8 & -1.3 & -1.0 & -2.3 & -1.4 & -2.5 & -0.6 \\
\hline RMSE & 3.6 & 2.8 & 2.0 & 1.5 & 6.4 & 5.7 & 4.2 & 2.8 \\
\hline NRMSE & 0.28 & 0.21 & 0.24 & 0.20 & 0.38 & 0.33 & 0.41 & 0.23 \\
\hline$r$ & 0.72 & 0.91 & 0.81 & 0.96 & 0.81 & 0.88 & 0.81 & 0.91 \\
\hline Slope & 0.8 & $0.7 *$ & 1.0 & $1.4^{*}$ & 1.0 & 1.1 & 0.7 & $1.3^{*}$ \\
\hline Intercept & 1.6 & 2.3 & -1.3 & -5.1 & -1.6 & -4.4 & 0.7 & -5.3 \\
\hline$d$ & 0.84 & 0.91 & 0.81 & 0.89 & 0.87 & 0.92 & 0.85 & 0.90 \\
\hline
\end{tabular}

${ }^{\mathrm{a}}$ Mean difference $=\sum($ observed-predicted $) / n$ where $n$ is the number of observations.

${ }^{\mathrm{b}}$ Root mean square error: $\left.R M S E=\sum[\text { (predicted-observed })^{2} / n\right]^{1 / 2}$.

${ }^{\mathrm{c}}$ Normalized root mean square error: NRMSE $=\mathrm{RMSE} /$ observed mean.

${ }^{\mathrm{d}} d=$ Willmott's index of agreement.

*Slope estimates or intercepts significantly different from 1.0 and 0.0 , respectively, at $\alpha=0.05$.

$r$ and $d$ were between 0.65 and 0.77 and 0.78 and 0.86 , respectively. The slopes $(0.6-1.2)$ and the intercepts $\left(0.4\right.$ to $\left.-6.0 \mathrm{mg} \mathrm{L}^{-1}\right)$ significantly differed from 1.0 and equaled 0.0 , respectively, indicating an overestimation of the measured data.
On a seasonal basis, simulated and measured drain flow $\mathrm{NO}_{3}-\mathrm{N}$ concentrations matched well, and no large deviations occurred in their trends (Figure 3). Mean values of measured and simulated $\mathrm{NO}_{3}-\mathrm{N}$ concentrations were close to each 
Clay loam
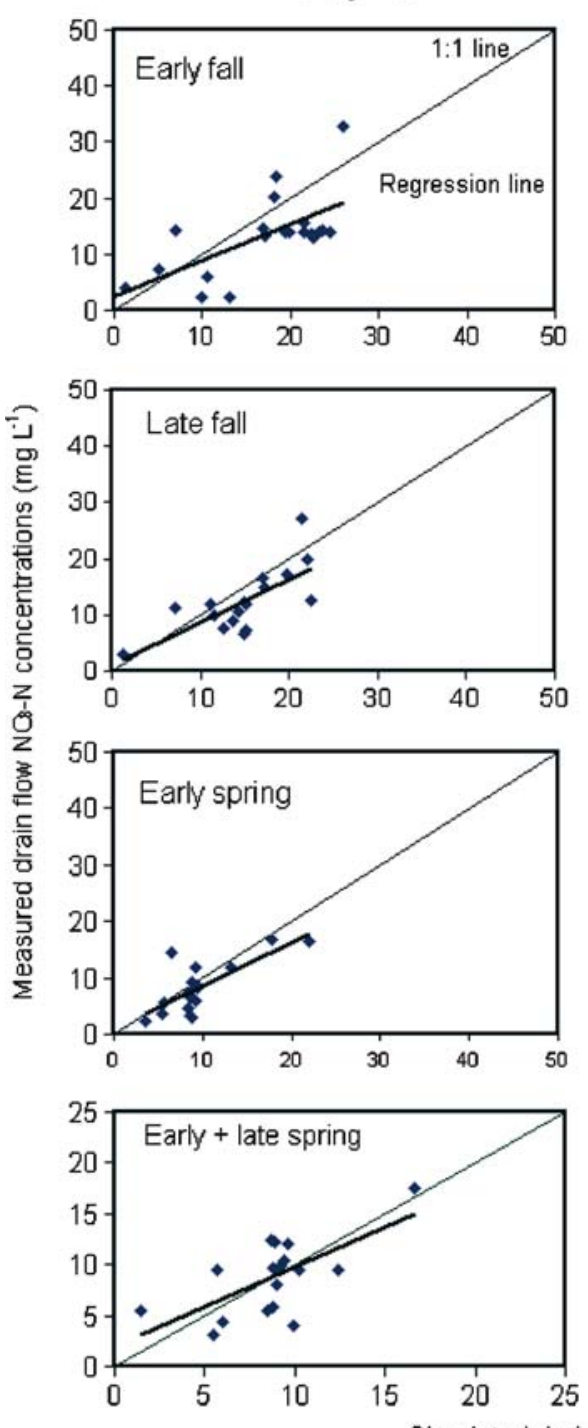

\section{Loamy sand}
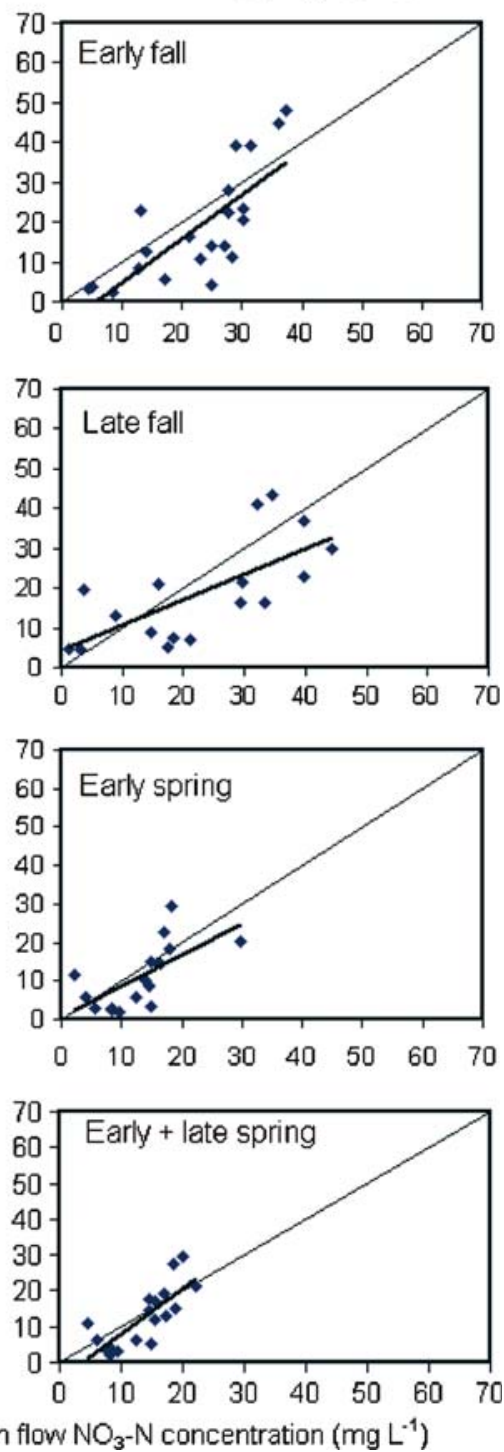

Figure 2. 1:1 scale plot and regression of measured and PNM-simulated values of monthly average drain flow $\mathrm{NO}_{3}-\mathrm{N}$ concentration during model calibration.

other (mean difference ranging from -2.5 to $-0.6 \mathrm{mg} \mathrm{L}^{-1}$, Table 6). For the clay loam soil, the RMSE values were between 1.5 and $3.6 \mathrm{mg} \mathrm{L}^{-1}$, leading to prediction errors of 20 $28 \%$ for the 3-yr measured mean values. Measured and simulated data sets were highly correlated and agreed well, with $r$ and $d$ ranging from 0.72 to 0.96 and 0.81 to 0.91 , respectively. The slopes (0.8 and 1.0) and intercepts $(-1.3$ and $1.6 \mathrm{mg} \mathrm{L}^{-1}$ ) for the early fall and early spring treatments were not significantly different from
1.0 and 0.0 , respectively, at $\alpha=0.05$, indicating that measured and simulated data were similar under those treatments. Under the late fall and early + late treatments, the slopes $(0.7$ and 1.4$)$ and intercepts $\left(-5.1\right.$ and $\left.2.3 \mathrm{mg} \mathrm{L}^{-1}\right)$ significantly differed from 1.0 and equaled 0.0 , respectively. For the loamy sand soil, the RMSE ranged from 2.8 to $6.4 \mathrm{mg} \mathrm{L}^{-1}$, resulting in $23-41 \%$ prediction errors of the 3 -yr measured mean values, and the $r$ and $d$ were between $0.81-0.91$ and $0.85-0.92$, respectively (Table 6). Three out of the four 
Clay loam
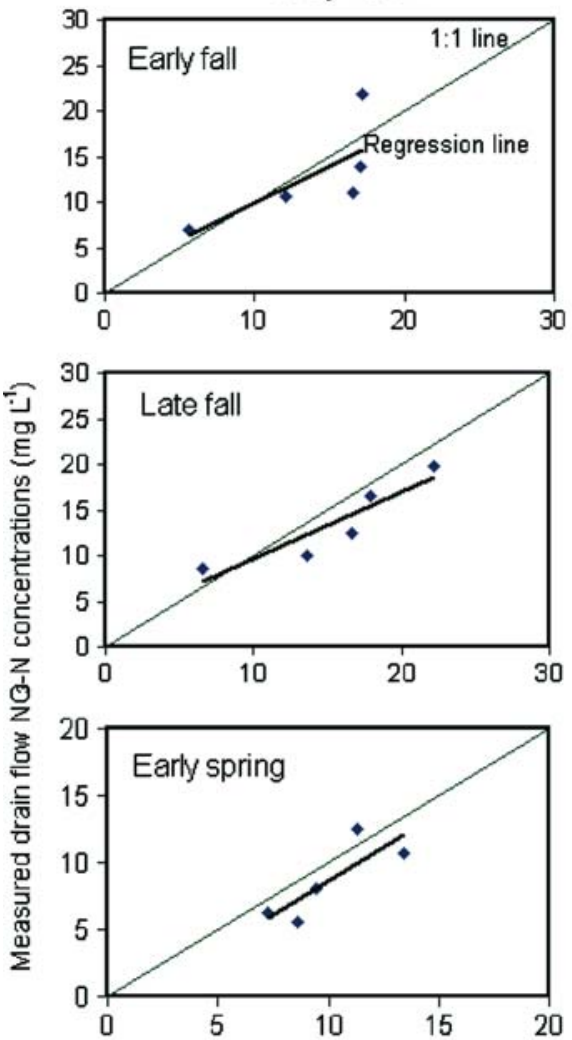

Loamy sand
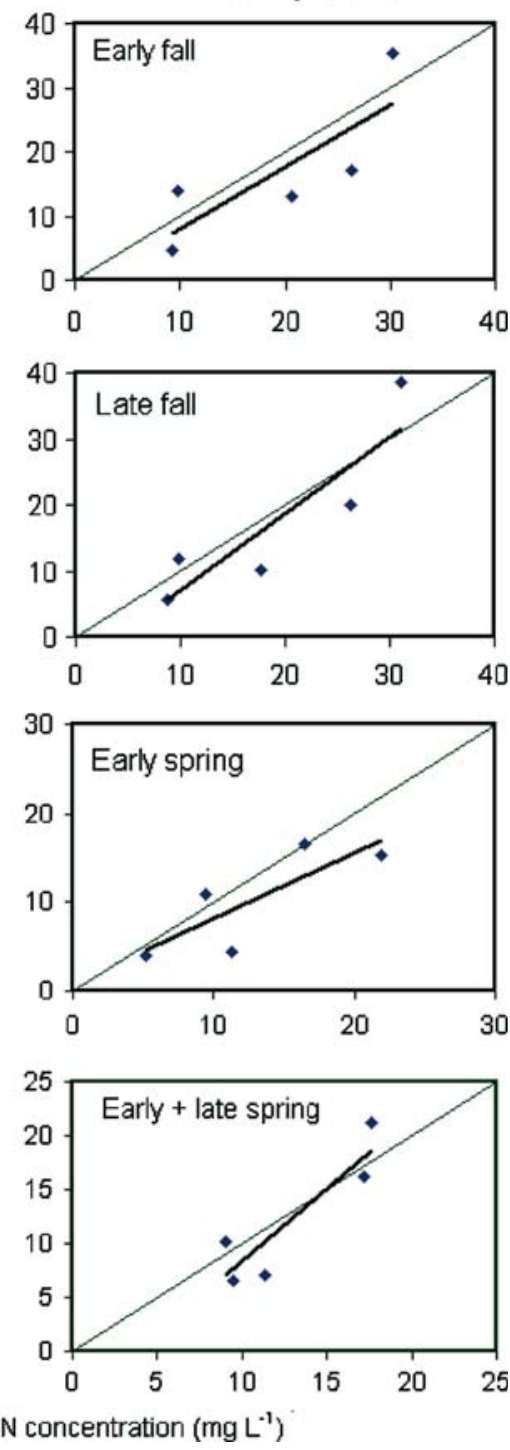

Figure 3. 1:1 scale plot and regression of measured and PNM-simulated values of seasonal average drain flow $\mathrm{NO}_{3}$ - $\mathrm{N}$ concentration during model calibration.

slopes and all the intercepts were not significantly different from 1.0 to 0.0 , respectively, at $\alpha=0.05$, indicating that in most cases measured and simulated drain flow $\mathrm{NO}_{3} \mathrm{~N}$ concentrations were similar.

The prediction errors ranged from 20 to $50 \%$ and 23 to $57 \%$ for the clay loam and loamy sand soils, respectively (Table 6). In addition, most of the residual values were between -4 and 4 and -10 and $10 \mathrm{mg} \mathrm{L}^{-1}$ for the clay loam and loamy sand soils, respectively (Figure 4). This demon- strates that the simulations were somewhat better for the clay loam than the loamy sand.

\section{Model performance}

When calibrated rate constant values averaged over manure timing of application treatments for each soil type were used to simulate monthly drain flow $\mathrm{NO}_{3}-\mathrm{N}$ concentrations, the PNM model performed well on both the clay loam and loamy sand soils, with slightly superior precision 

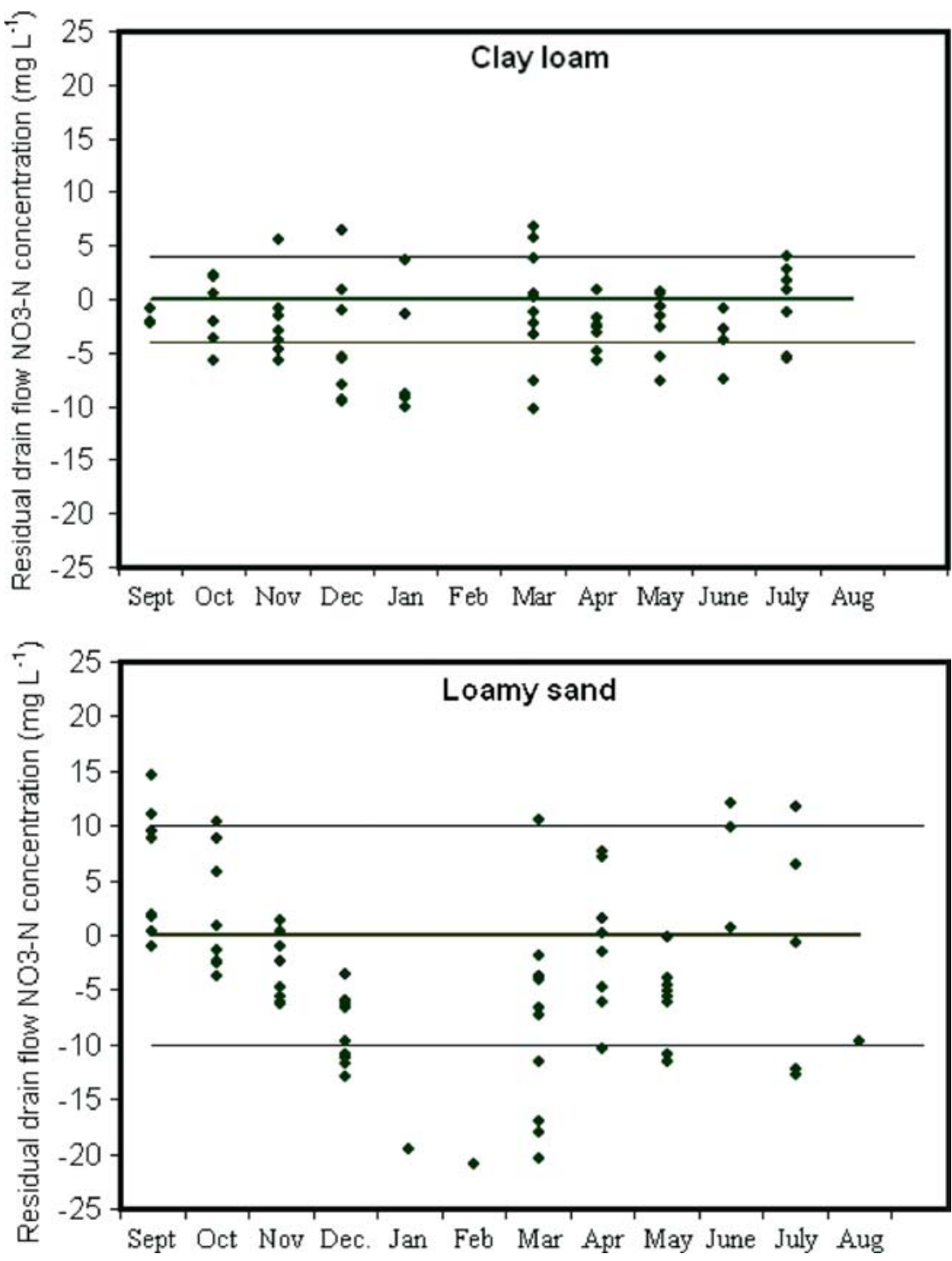

Figure 4. Residual values of measured minus simulated monthly average drain flow $\mathrm{NO}_{3}-\mathrm{N}$ concentrations during model calibration on the clay loam and loamy sand soils.

for the clay loam (Table 7). The 3-yr mean differences $\left(-2.8\right.$ to $\left.0.4 \mathrm{mg} \mathrm{L}^{-1}\right)$ were reasonably similar to the -3.9 to $0.1 \mathrm{mg} \mathrm{L}^{-1}$ values determined during model calibration. The RMSE values ranged from 2.9 to 6.9 and 5.3 to $9.7 \mathrm{mg} \mathrm{L}^{-1}$, resulting in 33 to $51 \%$ and 42 to $56 \%$ prediction errors for the clay loam and loamy sand soils, respectively (Table 7), which were similar to values determined for model calibration (38 to $50 \%$ and 42 to $57 \%$, for the clay loam and loamy sand soils, respectively). For the two soil types, the $r$ and $d$ ranged from 0.54 to 0.81 and 0.70 to 0.84 , respectively, which were similar, or slightly lower or higher compared to the 0.63 to 0.77 and 0.72 to 0.84 values obtained during model calibration. Six ( 0.6 to 0.8$)$ out of the eight slopes ( 0.6 to 1.2$)$ were significantly less than 1.0 and all the intercepts $\left(-6.0\right.$ to $\left.4.2 \mathrm{mg} \mathrm{L}^{-1}\right)$ were not significantly different from 0.0 at $\alpha=0.05$ (Table 7), indicating a general tendency of overestimation of the measured data. For the seasonal simulations, the mean difference ranged from -4.3 to $0.7 \mathrm{mg} \mathrm{L}^{-1}$, and the RMSE values $\left(6.9\right.$ to $\left.1.9 \mathrm{mg} \mathrm{L}^{-1}\right)$ resulted in 15 to $50 \%$ prediction errors which 
Table 7. Statistics for simulation of drain flow $\mathrm{NO}_{3}-\mathrm{N}$ concentration $\left(\mathrm{mg} \mathrm{L}^{-1}\right)$ by the PNM model during model testing using rate constants averaged over manure application treatments for each site (site average, Table 5)

\begin{tabular}{|c|c|c|c|c|c|c|c|c|}
\hline \multirow[t]{2}{*}{ Statistics } & \multicolumn{4}{|c|}{ Clay loamy } & \multicolumn{4}{|c|}{ Loamy sand } \\
\hline & $\begin{array}{l}\text { Early } \\
\text { fall }\end{array}$ & $\begin{array}{l}\text { Late } \\
\text { fall }\end{array}$ & $\begin{array}{l}\text { Early } \\
\text { spring }\end{array}$ & $\begin{array}{l}\text { Early + late } \\
\text { spring }\end{array}$ & $\begin{array}{l}\text { Early } \\
\text { fall }\end{array}$ & $\begin{array}{l}\text { Late } \\
\text { fall }\end{array}$ & $\begin{array}{l}\text { Early } \\
\text { spring }\end{array}$ & $\begin{array}{l}\text { Early + late } \\
\text { spring }\end{array}$ \\
\hline \multicolumn{9}{|c|}{ Monthly simulations } \\
\hline Mean difference & 0.4 & -0.3 & -2.0 & -0.6 & -2.3 & -1.9 & -2.8 & -1.6 \\
\hline RMSE & 6.1 & 4.1 & 4.2 & 2.9 & 9.7 & 9.0 & 6.3 & 5.3 \\
\hline NRMSE & 0.46 & 0.33 & 0.51 & 0.33 & 0.51 & 0.47 & 0.56 & 0.42 \\
\hline$r$ & 0.54 & 0.69 & 0.65 & 0.66 & 0.73 & 0.76 & 0.71 & 0.81 \\
\hline Slope & $0.7^{*}$ & $0.8^{*}$ & $0.6^{*}$ & $0.7 *$ & $1.1^{*}$ & $0.8^{*}$ & $0.8^{*}$ & $1.2^{*}$ \\
\hline Intercept & 4.0 & 2.2 & 1.6 & 2.3 & -3.7 & 3.0 & -0.3 & -4.5 \\
\hline$d$ & 0.70 & 0.82 & 0.78 & 0.80 & 0.81 & 0.86 & 0.80 & 0.84 \\
\hline \multicolumn{9}{|c|}{ Seasonal simulations } \\
\hline Mean difference & 0.7 & -0.3 & -2.5 & -1.7 & 0.1 & 0.7 & -4.3 & -2.4 \\
\hline RMSE & 3.9 & 2.1 & 2.9 & 1.9 & 6.7 & 6.9 & 5.1 & 3.4 \\
\hline NRMSE & 0.30 & 0.15 & 0.33 & 0.24 & 0.39 & 0.40 & 0.50 & 0.29 \\
\hline$r$ & 0.65 & 0.93 & 0.84 & 0.97 & 0.75 & 0.83 & 0.90 & 0.92 \\
\hline Slope & 0.8 & $0.7^{*}$ & 0.9 & $1.3^{*}$ & 1.0 & 1.3 & $0.7^{*}$ & $1.1^{*}$ \\
\hline Intercept & 2.8 & 3.4 & -1.2 & -4.7 & -0.8 & -4.5 & -0.7 & -4.7 \\
\hline$d$ & 0.78 & 0.94 & 0.75 & 0.86 & 0.83 & 0.85 & 0.82 & 0.90 \\
\hline
\end{tabular}

*Slope estimates or intercepts significantly different from 1.0 and 0.0 , respectively, at $\alpha=0.05$.

were reasonably close to the 20 to $41 \%$ values determined for model calibration data sets (Table 7). Measured and simulated data were highly correlated ( $r$ between 0.65 and 0.97 ) and agreed well ( $d$ between 0.75 and 0.94 ) similar to the calibration effort ( $r$ and $d$ ranging from 0.72 to 0.96 and 0.84 to 0.92 , respectively). Four ( 0.8 to 1.3$)$ out of the eight slopes (0.7 to 1.3$)$ and all the intercepts $\left(-4.7\right.$ to $\left.2.8 \mathrm{mg} \mathrm{L}^{-1}\right)$ were not significantly different from 1.0 and 0.0 , respectively, at $\alpha=0.05$.

Model performance varied somewhat among seasons and between soil types when calibrated rate constant values were averaged over both timing of manure application and soil type for the monthly simulations. The model performed well during the fall time application of manure on the clay loam soil, with prediction error, $r$ and $d$ of 41 and $49 \%, 0.60$ and 0.73 , and 0.72 and 0.79 , respectively (Table 8 ), which were similar to the 38 and $50 \%, 0.63$ and 0.69 , and 0.72 and 0.81 values, respectively, for model calibration data sets. Simulations were only satisfactory for the spring time of manure application on the clay loam soil and for both the fall and the spring times for the loamy sand soil. This resulted in higher prediction errors (48 to $73 \%$ ) and lower $r(0.53$ to 0.69$)$ and $d(0.61$ to 0.74$)$ compared to the 31 to $57 \%, 0.65$ to 0.80 , and 0.78 to 0.85 values, respectively, determined for the calibration data sets. Seven out of the eight slopes and all intercepts for the monthly simulations were significantly different from 1.0 and similar to 0.0 , respectively at $\alpha=0.05$. On a seasonal basis, simulations followed similar trends as those for the monthly simulations, being accurate for the fall time manure application on the clay loam soil and satisfactory for the spring time on the clay loam and the fall and spring times on the loamy sand soil. For the fall time manure application on the clay loam, the prediction error, $r$ and $d$ values were 26 and $29 \%, 0.75$ and 0.91, and 0.88 and 0.92 , respectively (Table 8), which were similar to the 21 and $28 \%$, 0.72 and 0.91 , and 0.84 and 0.91 values, respectively, obtained during model calibration. For the spring time on the clay loam and the fall and spring times on the loamy sand soil, the prediction errors (32 to $56 \%$ ) were higher and the $r$ (0.61 to 0.90$)$ and $d(0.63$ to 0.84$)$ were lower than the 20 to $41 \%, 0.81$ to 0.96 , and 0.81 to 0.92 values, respectively, determined for the 
Table 8. Statistics for simulation of drain flow $\mathrm{NO}_{3}-\mathrm{N}$ concentration $\left(\mathrm{mg} \mathrm{L}^{-1}\right)$ by the PNM model during model testing using rate constants averaged over manure application treatments and soil types (across site average, Table 5)

\begin{tabular}{|c|c|c|c|c|c|c|c|c|}
\hline \multirow[t]{2}{*}{ Statistics } & \multicolumn{4}{|c|}{ Clay loamy } & \multicolumn{4}{|c|}{ Loamy sand } \\
\hline & Early fall & Late fall & Early spring & Early + late spring & Early fall & Late fall & Early spring & Early + late spring \\
\hline \multicolumn{9}{|c|}{ Monthly simulations } \\
\hline Mean difference & -2.1 & -3.1 & -3.6 & -2.5 & 3.7 & 5.3 & -1.1 & -0.2 \\
\hline RMSE & 6.6 & 5.2 & 6.0 & 4.5 & 12.6 & 11.6 & 6.6 & 6.1 \\
\hline NRMSE & 0.49 & 0.41 & 0.73 & 0.52 & 0.67 & 0.61 & 0.59 & 0.48 \\
\hline$r$ & 0.60 & 0.73 & 0.56 & 0.58 & 0.48 & 0.57 & 0.58 & 0.69 \\
\hline Slope & $0.7^{*}$ & $0.7^{*}$ & $0.4^{*}$ & $0.4^{*}$ & $1.1^{*}$ & $1.1^{*}$ & $0.8^{*}$ & $1.2 *$ \\
\hline Intercept & 3.0 & 1.1 & 2.9 & 3.7 & 2.3 & 4.3 & 1.3 & -3.0 \\
\hline$d$ & 0.72 & 0.79 & 0.67 & 0.68 & 0.58 & 0.63 & 0.72 & 0.74 \\
\hline \multicolumn{9}{|c|}{ Seasonal simulations } \\
\hline Mean difference & -1.4 & -2.5 & -3.7 & -3.2 & 3.4 & 3.9 & -1.8 & -0.5 \\
\hline RMSE & 3.8 & 3.5 & 4.1 & 3.4 & 8.7 & 9.7 & 4.1 & 3.8 \\
\hline NRMSE & 0.29 & 0.26 & 0.48 & 0.44 & 0.51 & 0.56 & 0.39 & 0.32 \\
\hline$r$ & 0.75 & 0.91 & 0.82 & 0.90 & 0.61 & 0.68 & 0.75 & 0.81 \\
\hline Slope & 0.8 & $0.7^{*}$ & $0.7^{*}$ & $0.9^{*}$ & 1.1 & 1.5 & 0.8 & 1.4 \\
\hline Intercept & 1.7 & 2.6 & 0.2 & -2.6 & 0.9 & -3.1 & 1.0 & -5.7 \\
\hline$d$ & 0.92 & 0.88 & 0.68 & 0.72 & 0.63 & 0.63 & 0.84 & 0.81 \\
\hline
\end{tabular}

*Slope estimates or intercepts significantly different from 1.0 and 0.0 , respectively, at $\alpha=0.05$

calibration data sets. Five (0.8 to 1.5$)$ of the eight (0.7 to 1.5$)$ slopes and all the intercepts were not significantly different from 1.0 and 0.0 , respectively, at $\alpha=0.05$.

\section{Discussion}

The simulation results indicated that the model tends to overestimate drain flow $\mathrm{NO}_{3}-\mathrm{N}$ concentrations on both the clay loam and loamy sand soils. This might in part be the result of the different time scales for the measured and simulated data. The PNM model functions on a daily time interval and therefore estimates the average drain flow $\mathrm{NO}_{3}-\mathrm{N}$ concentration for a day. But our measured data were based on drain flow samples obtained at a given time of the day, and may not perfectly reflect the concentration for the entire day.

For both the clay loam and loamy sand soils, the largest disagreements between simulated and measured data occurred during the period November-December (Figure 4). This suggests that the model has some limitations in realistically describing water flow and associated chemi- cal concentrations during soil thawing and/or snow conditions. Modeling studies addressing manure- $\mathrm{N}$ dynamics, particularly $\mathrm{NO}_{3}-\mathrm{N}$ leaching are rare. In evaluating the LEACHN model for simulating monthly $\mathrm{NO}_{3}-\mathrm{N}$ leaching losses from two manured treatments under a maize crop, Jemison et al. (1994b) determined prediction error and $r$ values typically ranging from 35 to $155 \%$ and 0.11 to 0.85 , respectively, for their calibration data. In our study, measured and simulated monthly drain flow $\mathrm{NO}_{3}-\mathrm{N}$ concentrations during model calibration agreed well ( $d$ between 0.72 and 0.86 ), were reasonably highly correlated ( $r$ ranging from 0.63 to 0.77 ), and the prediction errors for the 3 -yr period measured mean values were between 31 and $57 \%$. This demonstrates that the PNM model appears suitable for successful simulations of $\mathrm{N}$ dynamics under a manure-fertilized maize crop.

When Jemison et al. (1994b) tested the performance of the LEACHN model after calibration, they reported correlation coefficients ranging from 0.22 to 0.85 between measured and simulated monthly $\mathrm{NO}_{3}-\mathrm{N}$ leached and prediction errors between 72 and $226 \%$. Our study attempted to simulate average monthly drain flow $\mathrm{NO}_{3}-\mathrm{N}$ 
concentrations, which may be more challenging than simulation of monthly mass of $\mathrm{NO}_{3}-\mathrm{N}$ leached. However, the statistics for model performance in our study were similar or better than those published by Jemison et al. (1994b). Furthermore, Marchetti et al. (2004) used the coupled MACRO-SOILN model to predict soil $\mathrm{NO}_{3}-\mathrm{N}$ content under a manure-fertilized maize crop. Their simulated values were up to $104 \%$ higher or $88 \%$ lower than the measured values. This suggests that the use of the PNM model for predicting $\mathrm{N}$ dynamics in manure-fertilized maize cropping is promising.

\section{Conclusions}

This study evaluated the PNM model for simulating drain flow $\mathrm{NO}_{3}-\mathrm{N}$ concentrations under a manure-fertilized maize crop on clay loam and loamy sand soils. It was established that upon calibration, the model is robust enough to reasonably accurately represent (index of agreement between 0.70 and 0.94 ) monthly and seasonal drain flow $\mathrm{NO}_{3}-\mathrm{N}$ concentrations from single $\mathrm{N}$ transformation rate constants on each soil type regardless of the timing of manure application, with better performance on the clay loam soil. The model proved capable of satisfactorily simulating (index of agreement between 0.72 and 0.92 ) monthly and seasonal drain flow $\mathrm{NO}_{3}-\mathrm{N}$ concentrations from $\mathrm{N}$ transformation rate constant values averaged over timing of manure application treatments and soil types for the fall time manure application on the clay loam, but showed lesser performance (index of agreement between 0.58 and 0.84 ) during spring time on the clay loam and the spring and fall times on the loamy sand soil. In general, the model tends to slightly overestimate drain flow $\mathrm{NO}_{3}-\mathrm{N}$ concentrations, in part because the comparisons challenged the temporal resolution of measured data. Furthermore, the model is limited with regard to simulating drain $\mathrm{NO}_{3}-\mathrm{N}$ concentrations under soil thawing and/or snow conditions. There appears to be room for improvement in the PNM model with regard to estimating chemical fluxes when conditions for lateral flow are significant and under frozen soil conditions, but the use of the model for predicting $\mathrm{N}$ dynamics in manurefertilized maize cropping appears promising.

\section{Acknowledgement}

The authors acknowledge the assistance of Bill Jokela (University of Vermont), Larry Geohring, Michael David, Delvin Meseck, Michael LaDuke, and Robert Lucey in the execution of this study, and funding support from the Northern New York Agricultural Development Program.

\section{References}

Addiscott T M and Whitmore A P 1987 Computer simulation of changes in soil mineral nitrogen and crop nitrogen during autumn, winter, and spring. J. Agri. Sci. Camb. 109, 141-157.

Ahuja L R, Rojas K W, Hanson J D, Shaffer M J and Ma L 2000 Root Zone Water Quality Model: Modeling Management Effects on Water Quality and Crop Production. Water Resources Publications, LLC, Highlands Ranch, CO, USA. $372 \mathrm{pp}$.

Ball-Coelho B R, Roy R C and Bruin A J 2004 Nitrate leaching as affected by liquide swine manure and cover cropping in sandy soil of southern Ontario. Can. J. Soil Sci. 2, 187-197.

Barbarika A Jr, Sikora L J and Colacicco D 1985 Factors affecting the mineralization of nitrogen in sewage sludge applied to soils. Soil Sci. Soc. Am. J. 49, 1403-1406.

Beraud J, Fine P, Yermiyahu U, Keinan M, Rosenberg R, Hadas A and Bar-Tal A 2005 Modeling carbone and nitrogen transformations for adjustment of compost application with nitrogen uptake by wheat. J. Environ. Qual. 34, 664-675.

Bernal M P and Kirchmann H 1992 Carbon and nitrogen mineralization and ammonia volatilization from fresh, aerobically and anerobically treated pig manure during incubation with soil. Biol. Fertil. Soils. 13, 135-141.

Borg G Ch, Jansson P E and Linden B 1990 Simulated and measured nitrogen conditions in a manured and fertilized soil. Plant Soil 121, 251-267.

Campbell G 1974 A simple method for determining unsaturated conductivity from moisture retention data. Soil Sci. 117, 311-314.

Cornell Cooperative Extension 1997 Cornell Recommendations for Integrated Field Crop Management. Cornell Univ., Ithaca, NY.

Cornell Nutrient Analysis Laboratories 1987 Phosphorus and nitrate calorimetric determinations by autoanalyzer. In Methods for Soil Fertility Analysis. Eds. M C McCenahan and G A Ferguson. pp. 7-16. Procedure No s1101. Cornell Univ., Ithaca, NY.

Cornell Nutrient Analysis Laboratories 1989 Extraction of soil for "available" nutrients. In Methods for Soil Fertility Analysis. Eds. M C McCenahan and G A Ferguson. pp. 3-6. Procedure No s1100. Cornell Univ., Ithaca, NY.

Desmond E D and Ward A D 2000 ADAPT: Agricultural Drainage and Pesticide Transport model. User manual. Version 5.1. Department of Agricultural Engineering, Ohio State University, Columbus, Ohio.

Donnigan A S Jr 1983 Model predictions vs. field observations: the model validation/testing process. In Fate of Chemicals in 
the Environment. A. S. C. Symposium series 225. Eds. R I Swnn and A Schenronder. pp. 151-171. Am Chem. Soc., Washington, DC.

Douglas B F and Magdoff F R 1991 An evaluation of nitrogen mineralization indices for organic residues. J. Environ. Qual. 20, 368-372.

Durieux R P, Brown H J, Stewart E J, Zhao J Q, Jokela W E and Magdoff F R 1995 Implications of nitrogen management strategies for nitrate leaching potential-roles of nitrogen-source and fertilizer recommendation system. Agron. J. 87, 884-887.

Eghball B 2000 Nitrogen mineralization from field-applied beef cattle feedlot manure or compost. Soil Sci. Soc. Am J. 64, 2024-2030.

Gee G H and Bauder J W 1986 Particle size analysis. In Methods of Soil Analysis. Part 1 Agron Monogr 9. Ed. A Klute. pp. 383-411. 2nd edition, ASA and SSSA, Madison, WI.

Gangbazo G, Pesant A R, Couillard C D and Barnett G M 1995 Winter and early spring losses of nitrogen following late fall application of hog manure. Can. Agric. Eng. 37, 73-79.

Grant R F, Amrani M, Heaney D J, Wright R and Zhang M 2004 Mathematical modeling of phosphorus losses from land application of hog and cattle manure. J. Environ. Qual. 33, 210-231.

Gupta S, Munyankusi E, Moncrief J, Zvomuya F and Hanewall M 2004 Tillage and manure application effects on mineral nitrogen leaching from seasonally frozen soils. J. Environ. Qual. 33, 1238-1246.

Hadas A and Molina J A E 1993 Simulation of nitrogen assimilation by hetrotrophic soil microbial biomass. Physiol. Plant. 89, 664-668.

Hadas A and Portnoy R 1997 Rate of decomposition in soil and release of available nitrogen from cattle manure and municipal waste composts. Compost Sci. Util. 5, 48-54.

Hadas A, Kautsky L, Goek M and Kara E E 2004 Rates of decomposition of plant residues and available nitrogen in soil, related to residue composition through simulation of carbon and nitrogen turnover. Soil Biol. Biochem. 36, 255266.

Hanks J and Ritchie J T 1991 Modeling Plant and Soil Systems. American Society of Agronomy, Inc, Madison, WI, USA $545 \mathrm{pp}$.

Hansen E M, Thomsen I K and Hansen M N 2004 Optimizing farmyard manure utilization by varying the application time and tillage strategy. Soil Use Manage. 20, 173-177.

Hutson J L 2003 Leaching Estimation And Chemistry Model: A Process-Based Model of Water and Solute Movement, Transformations, Plant Uptake, and Chemical Reactions in the Unsaturated Zone. Version 4. Dept. of crop and Soil Sciences. Research series No. R03-1. Cornell Univ., Ithaca, NY, U.S.A.

Hutson J L and Wagenet R J 1991 Simulating nitrogen dynamics in soils using a deterministic model. Soil Use Manage. 7, 74-78.

Hutson J L and Wagenet R J 1992 LEACHM: Leaching Estimation And Chemistry Model: A Process-Based Model of Water and Solute Movement, Transformations, Plant Uptake, and Chemical Reactions in the Unsaturated Zone. Continuum Vol. 2, Version 3. Water Resources Inst., Cornell University, Ithaca, NY, U.S.A.

Jabro J D, Lotse J D, Fritton D D and Baker D E 1994 Estimation of preferential movement of bromide tracer under field conditions. J. Hydrol. 156, 61-71.
Jackson D R and Smith K A 1997 Animal manure slurries as a source of nitrogen for cereals; effect of application time on efficiency. Soil Use Manage. 13, 75-81.

Jansson P and Andersson R 1988 Simulation of runoff and nitrate leaching from an agricultural district in Sweden. J. Hydrol. 99, 33-47.

Jemison J M Jr 1991 Nitrate leaching from soil measured with zero-tension pan lysimeters as influenced by nitrogen fertilizer rate and manure application: field estimates and model predictions. Ph.D. diss. Pennsylvania State Univ., Univ. Park.

Jemison J M Jr, Jabro J D and Fox R H 1994a Evaluation of LEACHM: simulation of cumulative drainage, bromide leaching, and corn bromide uptake. Agron. J. 86, 843-851.

Jemison J M Jr, Jabro J D and Fox R H 1994b Evaluation of LEACHM: Simulation of nitrate leaching from nitrogenfertilized and manured corn. Agron. J. 86, 852-859.

Johnsson H, Bergström L, Jansson P and Paustian K 1987 Simulated nitrogen dynamics and losses in a layered agricultural soil. Agric. Ecosyst. Environ. 18, 333-356.

Klausner S D, Kanneganti V R and Bouldin D R 1994 An approach for estimating a decay series for organic nitrogen in animal manure. Agron. J. 86, 897-903.

Klute A and Dirksen C 1986 Hydraulic conductivity and diffusivity: laboratory methods. In Methods of Soil Analysis. Part 1 Agron Monogr 9, 2nd edition Ed. A Klute. pp. 687734. ASA, SSSA, Madison, WI.

Külling DR, Menzi H, Kröber TF, Neftel A, Sutter F, Lischer $P$ and Kruezer M 2001 Emissions of ammonia, nitrous oxide and methane from different types of daily manure during storage as affected by dietary protein content. Journal of Agricultural Science 137, 235-250.

Lauer D A, Bouldin D R and Klausner S D 1976 Ammonia volatilization from dairy manure spread on the soil surface. J. Environ. Qual. 5, 134-141.

Loague K and Green R E 1991 Statistical and graphical methods for evaluating solute transport models: overview and application. J. Contam. Hydrol. 7, 51-73.

Lotse E G, Jabro J D, Simmons K E and Baker D E 1992 Simulation of nitrogen dynamics and leaching from arable soils. J. Contam. Hydrol. 10, 183-196.

Ma L and Shaffer M J 2001. A review of carbon and nitrogen processes in nine U.S. soil nitrogen dynamic models. In Modeling Carbon and Nitrogen Dynamics for Soil Management. Eds. M J Shaffer, L Ma and S Hansen. 631 pp.

Magdoff F R 1978 Influence of manure application rates and continuous corn on soil N. Agron. J. 70, 629-632.

Magdoff F R 1991 Understanding the Magdoff pre-sidedress nitrate soil test for corn. J. Prod. Agric. 4, 297-305.

Marchetti R, Ponzini G and Spallacci P 2004 Simulating nitrogen dynamics in agricultural soils fertilized with pig slurry and urea. J. Environ. Qual. 33, 1217-1229.

Melkonian J J, van Es H M and Joseph L, 2005 Precision Nitrogen Model: Simulation of Nitrogen and Water Fluxes in the Soil-Crop-Atmosphere Continuum in Maize (Zea mays L.) Production Systems. Version 1.0. Dept. of Crop and Soil Sciences. Research series No. R05-2. Cornell Univ., Ithaca, NY, U.S.A.

Molina J A E, Clapp C E. and Hadas A 1990 Computer simulation of nitrogen turnover in soil and priming effect. Soil Biol. Biochem. 22, 349-353.

Muchow R C and Sinclair T R 1991 Water deficit on maize yields modeled under current and "greenhouse" climates. Agron. J. 83, 1052-1059. 
Muchow R C, Sinclair T R and Bernnett J M 1990 Temperature and solar radiation effects on potential maize yield across locations. Agron. J. 82, 338-343.

Mueller D K, Hamilton P A, Helsel D R, Hitt K J and Ruddy B C 1995 Nutrients in ground water and surface water of the United States - An analysis of data through 1992. WaterResource Investigations Report 95-4031. U.S. Dept. of the Interior, Geological Survey.

Paul J W and Zebarth B J 1997 Denitrification and nitrate leaching during the fall and winter following dairy cattle slurry application. Can. J. Soil Sci. 77, 231-240.

Pratt P F, Broodbent F E and Martin J P 1973 Using organic wastes as nitrogen fertilizers. Calif. Agric. 27, $10-13$.

SAS Institute 2004 SAS User's Guide. SAS Inst, Cary, NC.

Shaffer M J, Halvorson A D and Pierce F J 1991 Nitrate leaching and economic analysis package (NLEAP): model description and application. In Managing Nitrogen for Groundwater Quality and Farm Profitability. Ed. R F Follett et al. pp. 285-322. Soil Science Society of America, Inc, Madison, WI, USA.

Sinclair T R and Amir J 1992 A model to assess nitrogen limitations on the growth and yield of spring wheat. Field Crops Res. 30, 63-78.

Sinclair T R and Muchow R C 1995 Effect of nitrogen supply on maize yield: I. modeling physiological responses. Agron. J. 87, 632-641.

Smith K A and Chambers B J 1993 Utilizing the nitrogencontent of organic manures on farms-problems and practical solutions. Soil Use Manage. 9, 105-112.

Sogbedji J M, van Es H M, Yang C L, Geohring L D and Magdoff F R 2000 Nitrate leaching and N budget as affected by maize $\mathrm{N}$ fertilizer rate and soil type. J. Environ. Qual. 29, $1813-1820$.

Sogbedji J M, van Es H M and Hutson J L 2001a N fate and transport under variable cropping history and fertilizer rate on loamy sand and clay loam soils: calibration of the LEACHMN model. Plant and Soil 229, 57-70.

Sogbedji J M, van Es H M, Hutson $\mathbf{J}$ L and Geohring L D $2001 \mathrm{~b} \mathrm{~N}$ rate and transport under variable cropping history and fertilizer rate on loamy sand and clay loam soils: performance of LEACHMN using different calibration scenarios. Plant Soil 229, 71-82.

Sogbedji J M, van Es H M and Agbeko K L 2005 Modeling nitrogen dynamic under maize on ferralsols in Western Africa. Nutr. Cycl. Agroecosyst. (in press).

Sorensen P, Weisbjerg M R and Lund P 2003 Dietary effects on the composition and plant utilization of nitrogen in dairy cattle manure. J. Agricult. Sci. 141, 79-91.

van Alphen B J and Stoorvogel J J 2000 A methodology for precision nitrogen fertilization in high-input farming systems. Precis. Agr. 2, 319-332.

van Beek C L, van den Eerwegh G A P H, van Schaik F H, Velthof G L and Oenema O 2004 The contribution of dairy farming on peat soil to $\mathrm{N}$ and $\mathrm{P}$ loading of surface water. Nutr. Cycl. Agroecosyst. 1, 85-95.

van Es H M, Steenhuis T S, Geohring L D, Vermeulen J and Boll J 1991 Movement of surface-applied and soil-embodied chemicals to drainage lines in a well-structyred soil. In Preferential Flow. Eds.T J Gish and A Shirmohammadi. pp. 59-67. ASAE, St.

van Es H M and van Es C L 1993 Spatial nature of randomization and its effect on the outcome of field experiments. Agron. J. 85, 420-428.

van Es H M, Schindelbeck R R and Jokela W E 2004 Effect of manure application timing, crop, and soil type on phosphorus leaching. J. Environ. Qual. 33, 1070-1080.

van Es H M, Yang C L and Geohring L D 2005 Maize nitrogen response as affected by drainage variability and soil type. Precision Agriculture (in press).

Van Keulen H 1976 Evaluation of models. In Critical Evaluation of Systems Analysis in Ecosystem Research and Management. Eds. G W Arnold and C T de Wit. pp. 2229. Center for Agriculture Publishing and Documentation (PUDOC), Wageningen, Netherlands.

Williams J R 1995 The EPIC model. In Computer Models of Watershed Hydrology. Ed. V P Singh. pp. 909-1000. Water Resources Publications, Highlands Ranch, CO, USA.

Willmott C J 1981 On the validation of models. Phys. Geogr. 2, 184-194.

Section editor: H. Lambers 